\title{
The Impact of Public Works in Spain: Natural, constructed and destroyed landscape
}

\section{El impacto de las Obras Públicas en España: Paisaje natural, construido y destruido}

\author{
Mario Martín-Antón (Main Author, Corresponding Author) \\ Universidad Politécnica de Madrid. Profesor Aranguren 3, 28040 Madrid (Spain) \\ mario.martin.anton@alumnos.upm.es \\ Vicente Negro \\ Universidad Politécnica de Madrid. Profesor Aranguren 3, 28040 Madrid (Spain) \\ vicente.negro@upm.es \\ José María del Campo \\ Universidad Politécnica de Madrid. Profesor Aranguren 3, 28040 Madrid (Spain) \\ josemaria.delcampo@upm.es \\ José Santos López-Gutiérrez \\ Universidad Politécnica de Madrid. Profesor Aranguren 3, 28040 Madrid (Spain) \\ josesantos.lopez@upm.es \\ María Dolores Esteban \\ Universidad Politécnica de Madrid. Profesor Aranguren 3, 28040 Madrid (Spain) \\ mariadolores.esteban@upm.es
}

\author{
Manuscript Code: 688 \\ Date of Acceptance/Reception: 11.02.2017/18.09.2015 \\ DOI: $10.7764 /$ RDLC.16.1.82
}

\begin{abstract}
This article reflects on the relationship between the human being and nature. Nature is wild, dynamic, symbolic, and as slow in her evolution as she is dramatically quick in her catastrophes. Humankind is present on the planet, inhabits it, leaves its mark and, therefore, constructs with a meaning, that of "being in the world". Its action, through the construction of Civil Engineering Works and spread of cities, constitutes an external "aggression" which changes the natural surrounds. That relationship has evolved throughout the history of four phases (submission, adaptation, conquest and respect). This is how the concept of natural landscape, constructed landscape and destroyed landscape appears on the basis of functional, aesthetic, environmental, economic and abstraction criteria, where the item constructed settles into the physical environment.
\end{abstract}

Key words: Natural Landscape, constructed landscape, destroyed landscape, civil engineering, environment.

\section{Resumen}

Este artículo es una reflexión entre la relación del ser humano y la naturaleza. Ésta es salvaje, dinámica, simbólica, tan lenta en su evolución como dramáticamente vertiginosa en sus catástrofes. La humanidad está presente en el planeta, habita en él, deja su huella, y, por ello, construye con un sentido, el de "estar en el mundo". Su acción, a través de la construcción de Obras de Ingeniería Civil y la expansión de las ciudades, constituye una "agresión” externa que modifica el entorno natural. Esa relación ha pasado por cuatro etapas a lo largo de la historia (sumisión, adaptación, conquista y respeto). Así es como aparece el concepto de Paisaje Natural, Paisaje Construido y Paisaje Destruido sobre la base de los criterios funcionales, estéticos, ambientales, económicos y de abstracción donde se asienta la obra en el medio físico.

Palabras clave: Paisaje natural, paisaje construido, paisaje destruido, ingeniería civil, medio ambiente.

Introduction

Nature is a "place" for emotion. This reflection emerges from subjective perception in certain localities. They come to life and become wrapped in feelings and emotions. "Site" is beginning, origin, a general reference to a location which is not yet understood and has not become existential. Every construction work is a human action that turns a site into a place. It changes the location, gives character to the land, modules it, organizes it, gives it backbone and may even disorganize it, on the basis of an artistic and environmental creation whilst being respectful with it (Figure 1). 
In the conversion process from site to place conflicts arise between urban development pressures and conservation planning, and presents challenges for planners and landscape ecologists around the World (Sanderson et al., 2002). The idea of the bridge, "to cross over"; of the harbour, to "shelter"; of the dam, to "store water"; of the road, to "improve mobility"; of the lighthouse, to "guide"; of the castle, "to defend oneself"; of the town, to "live and live with"; of the church and monastery, to "pray or perceive silence", lead to constructing in order to transcend and acquire meaning (Egypt, Greece or Rome); or to occupy the natural setting, at times irrespectively and negligently. For some years now, we have also had to take into account the tunnel, to "shorten distances" and the airport, to "connect the world". This study is an investigation into the landscape, the place, the significance or attack on the natural location by the human being.

Figure 1. Golden Gate Strait before the construction of the bridge (Site) and afterwards (Place).Source: www.goldengate.org, Mario Martín-Antón

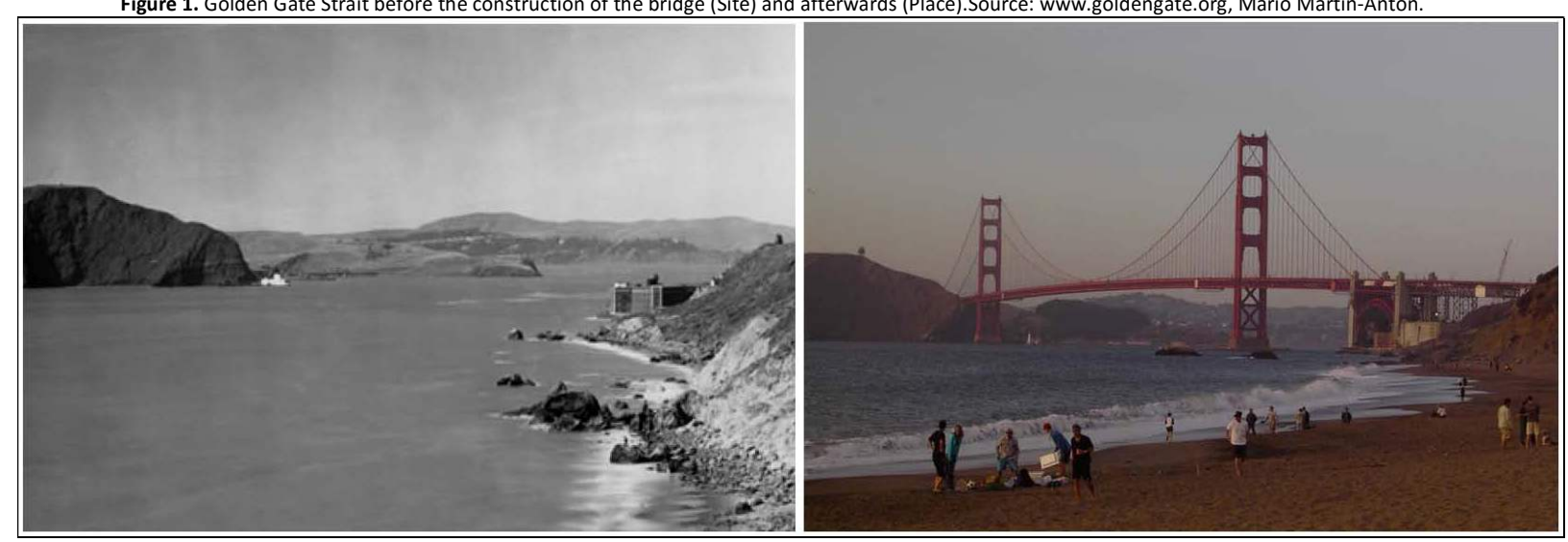

State of the Art: The four phases of the relationship between the human and the nature

The human being's evolution in the "art of construction and being in the world" (Aguiló, 2013) has moved through four stages with the passing of time (Aguiló, 1999). The search for high sites to make a defense from the enemies' attacks; river mouths to obtain water and shelter before departing for the violent ocean; paths and bridges to guarantee communication and mobility, led to the species passing through a first phase of "submission" (Figure 2) to, and even fear of nature. This vulnerability might not solely be determined by the human-environmental stress, but it might rather be influenced by the changes of society's adaptive capacities (Renaud et al., 2010).

Figure 2. Submission. Storm at the breakwater of Deba (Guipúzcoa), and flooding of the River Castro in Ventosa de Fuentepinilla (Soria). Source: Goio, www.diariovasco.com, Mario Martín-Antón.

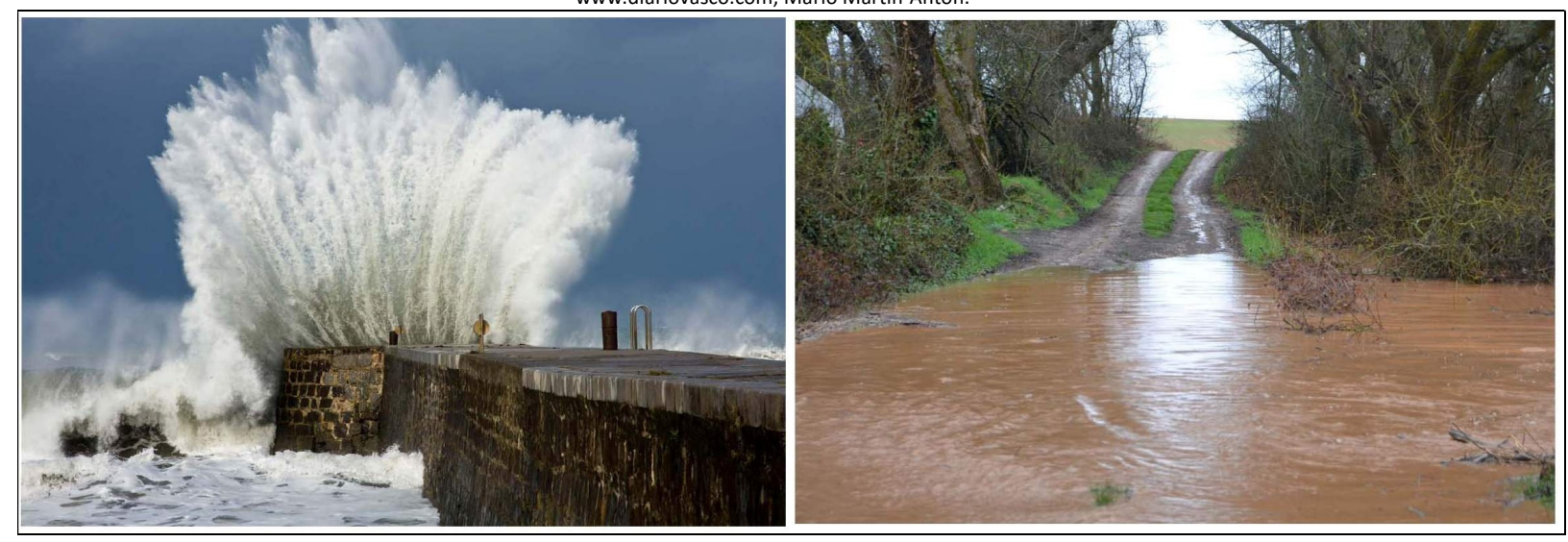

Agriculture, cattle rearing and trade together with an increase in population led to "adaptation" (Figure 3), a sedentary lifestyle and the birth and growth of towns and Communication Routes. Villages live and coexist within the town's framework. This second stage is characterized by construction works that minimize environmentally destructive impacts and the effective adaptation to and integration with nature's processes (Van der Ryn \& Cowan, 
2007). Both "submission" and "adaptation" extended over thousands of years. The human being appropriated the land over time. With his constructions, he demonstrated power and dominance and reached a third stage, the "conquest" (Figure 4), in this case, of nature (Aguiló, 1999).

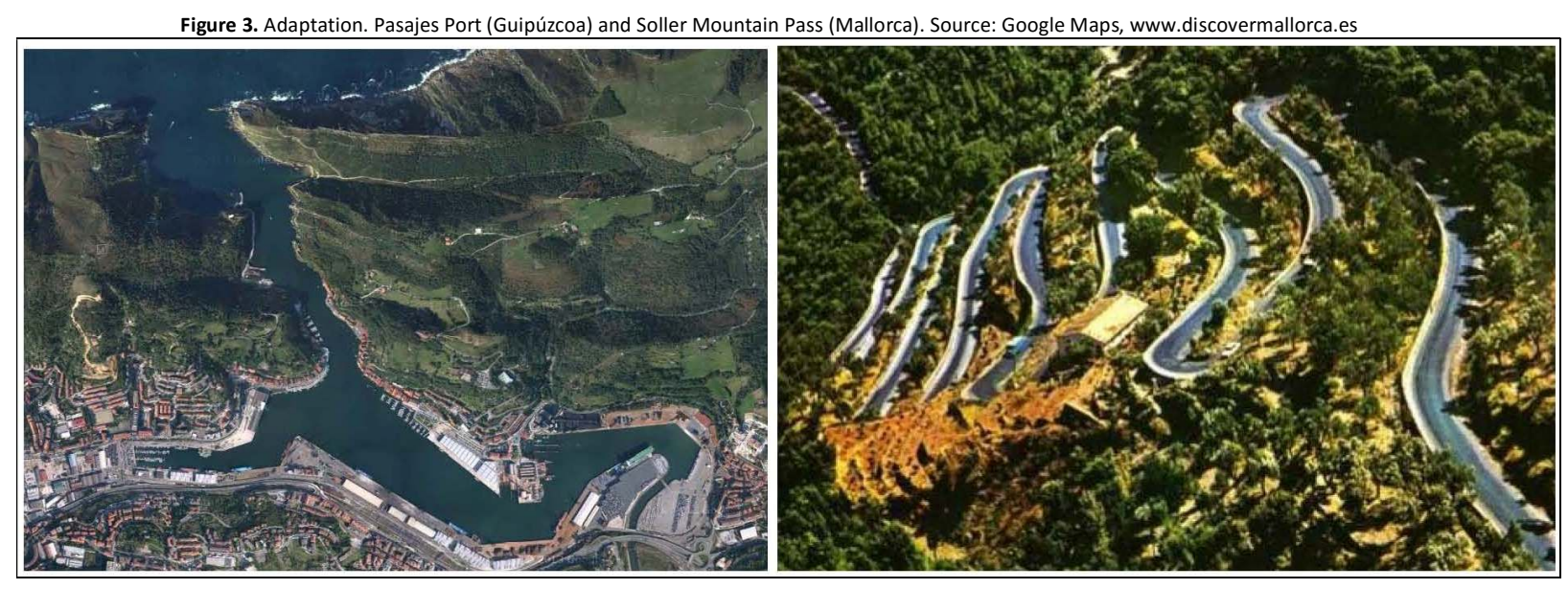

Figure 4. Conquest. Outer Port of Gijon (Asturias) and Los Tilos Viaduct (La Palma Island). Source: www.puertogijon.es, www.ferrovial.com

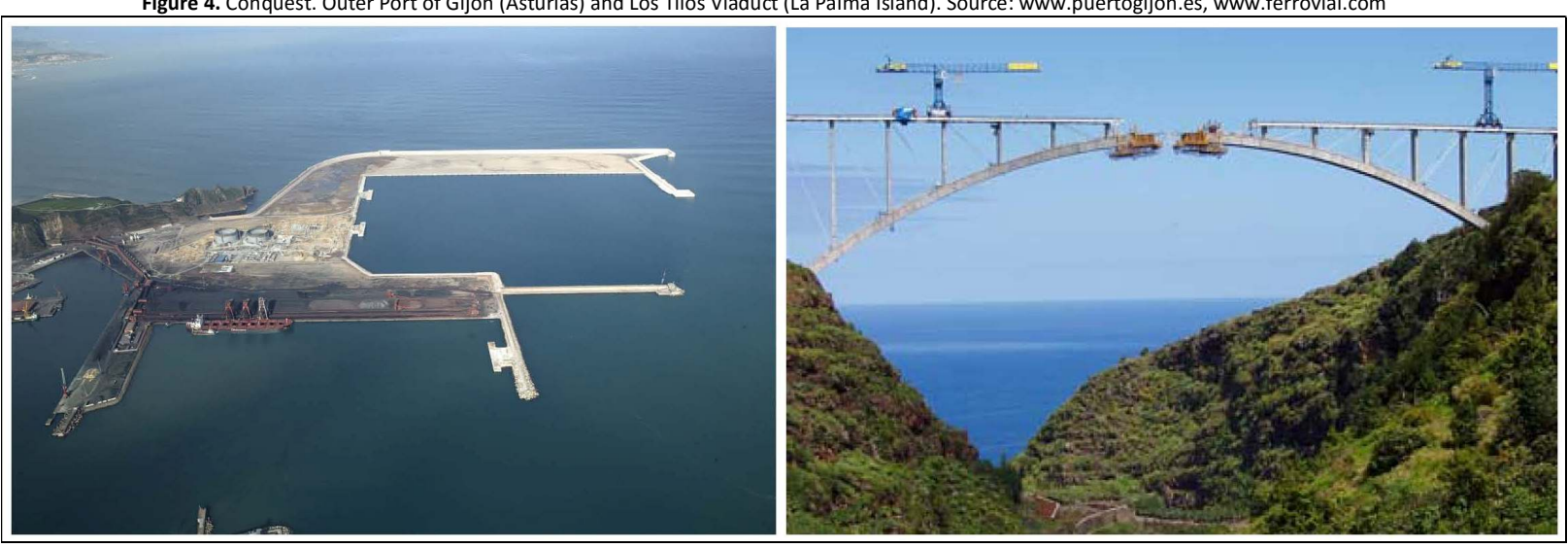

Figure 5. Respect. "Memory Cubes" in Llanes (Asturias) and "Thick Pine" on the A-601 road (Valladolid). Source: www.llanesnet.com, Google Maps.

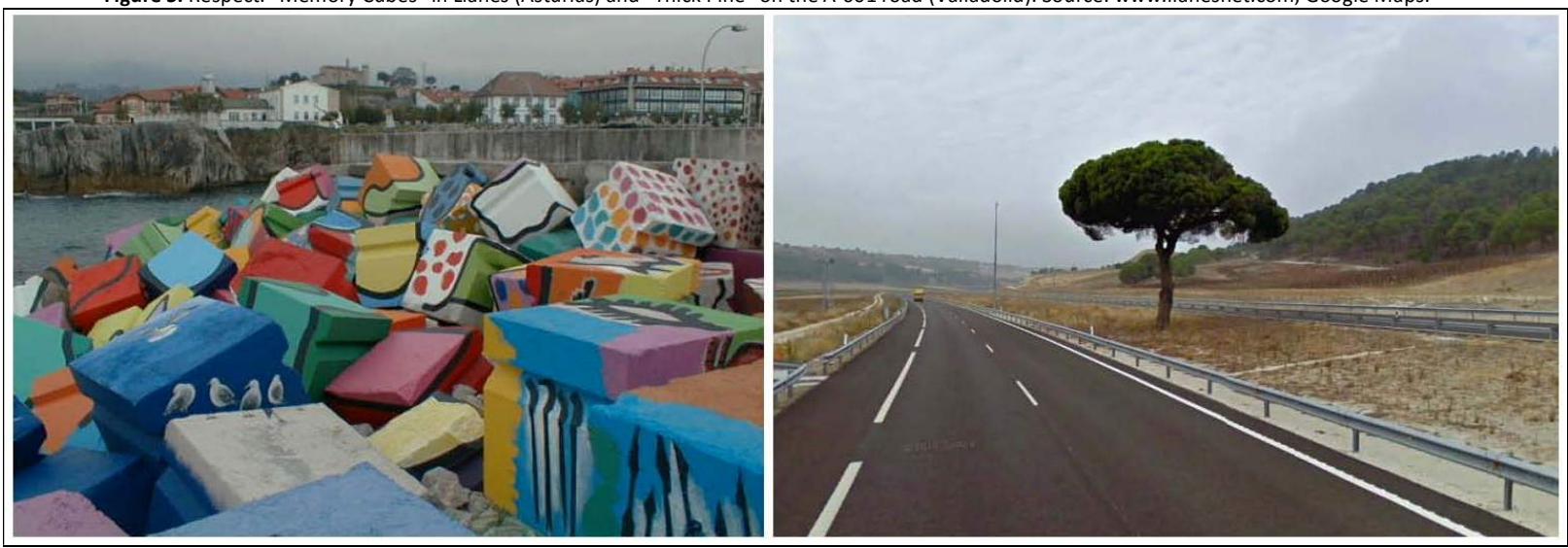

Caused by mass growth, the indiscriminate exploitation of natural resources, social and population inequalities, hostility towards the natural environment and lack of environmental sensitivity, over the last few decades, engineering has discovered and encouraged "respect" (Figure 5), cooperation with the surroundings, the "place" of 
emotion from where we have departed and to where we shall return, although it is true that some constructions undertaken in ancient times had that commitment (Aguiló, 1999).

How complicated will the future be and how obtuse the past if we do not preserve roots and land is fought over without perception, destroying instead of constructing, far from the "genius loci", from the spirit of the place, from the transcendence of the construction. This spirit gives life to people and places, accompanies them from birth to death, and determines their character or essence (Norberg-Schulz, 1979).

\section{Description of the problem: Transcendent and rash landscape}

The natural landscape is transformed by the art of constructing, by the relationship of the construction with nature, creating a new, emotional, living and, above all, transcendent landscape, the constructed landscape. Any other human action which alters, attacks and assaults the physical environment is framed within the concept of destroyed landscape. In the "built landscape or transcendent landscape" there is a magical link between the construction and the surroundings, transcending its own use and acquiring meanings" (Aguiló, 1999). The physical environment embodies new dimensions which, above all, are touching, and sentiments and emotions appear giving character to the land and granting its protagonism.

Other times, the conjunction between what is natural and what has been constructed is unfortunate, excessive, unsubstantial, unbalanced, lacking in meaning and disproportionate. The relationship connecting the action of constructing and what is natural is not an "art" but a failure to meet up, disorder, an inappropriate, negative transformation of surroundings, which disorganizes instead of giving backbone to and separates instead of drawing closer. This is the "destroyed or rash landscape".

The transformation of a location into a place, the visual and functional connection, the creative manifestation gives meaning to what is neutral by adding vegetation, water and climate to the relief, a human action modelling and modulating the land and "fabricating" landscape. The physical environment, human activity, history, culture and traditions configure the spirit and character of the place. "Beautiful landscapes are irreplaceable in that they fulfil our longing to be part of the natural World and heal the rift between subject and nature, both the nature out there and the nature in us" (Krebs, 2014). Nowadays, constructions are real symbols of towns if they have turned into the latter's constructed landscape. The perception of the Eiffel Tower in Paris during the 1889 Universal Exposition is different to the "symbol" it represents today. The same may happen with the Golden Gate in San Francisco (1937) (Figure 1) or the Segovia aqueduct (1st century A.D.). They have become facts when they were born as landmarks that yearned for utopia.

However, a construction often loses its roots, its meaning and essence. It is undertaken on the basis of inexistent needs, tackled for instrumental or economic reasons as a drive and impulse or a mistaken philosophy, to make it increasingly bigger and more useless. Nevertheless, this mistaken meaning also happens in small constructions, "in passing" which, in turn, are the most numerous and in which the priority of speed in construction or economics do not allow the designer to "think and repose" on what is going to transcend and change the physiognomy of the place (Thompson, 2002).

In this way, the shape is not fragmented, is integrated, becomes authentic and turns into a monument. It dominates the space and eliminates the void, becomes a dream and, with it, transcends constructed landscape. If it does not blend in, it breaks the balance with nature and then land becomes ill, losing its harmony and vertebration. Nature is assaulted, attacked, becomes defective, waiting for time to straighten up its gait. The new art may mean its dismantling, returning to the natural scenario, which is only fully recovered in most cases in long lapses of time.

Time, like space is two features of human actions on the environment to be considered separately (Turner et al., 1994). The question we should ask ourselves when intervening in the environment is: What does Nature want to be in this place? The answer depends on the spatial scale and timeframe, to identify its unique essence ("genius loci"), its aspirations and its potential (Du Plessis, 2012).

Discussion: Built and destroyed landscape in Spain

The target landscape is divided into two categories: necessary (constructed) and superfluous (destroyed); transcendent (constructed) and rash (destroyed); spiritual and symbolic (constructed) and inefficient and cold (destroyed); utopia, beauty and dream (constructed) as against useless, ugly and real (destroyed). A design must make itself loved, otherwise, testing must continue. Some of the many examples of civil engineering in Spain, the bridge, the 
road, the dam, the harbour and the coast plus the town where the foregoing thoughts are exemplified are reviewed below.

The integration and harmony of the Navalosa mediaeval bridge over the river Alberche (Ávila) has been altered and assaulted, challenging the initially natural landscape of the river's rough waters; later, to be built by the art of being in the world to communicate and guarantee mobility achieved with the arch bridge (Antrop, 2005). This construction grants the place a symbol, today broken by progress and the mass growth of rural tourism, which has demanded new, faster, safer means of transport but in no way integrated into the surroundings and to end up in a new construction. The piers of the new bridge clash in an unbalanced, rash dimension (Figure 6). Proper maintenance of heritage constructions is essential to avoid the risk of ruin and to avoid a new construction (González Rodrigo et al., 2015) but also a minimum care should be taken when building a new bridge next to a medieval one.

Figure 6. Navalosa bridge over the river Alberche (Ávila). Built landscape and destroyed landscape. Source: Vicente Negro.

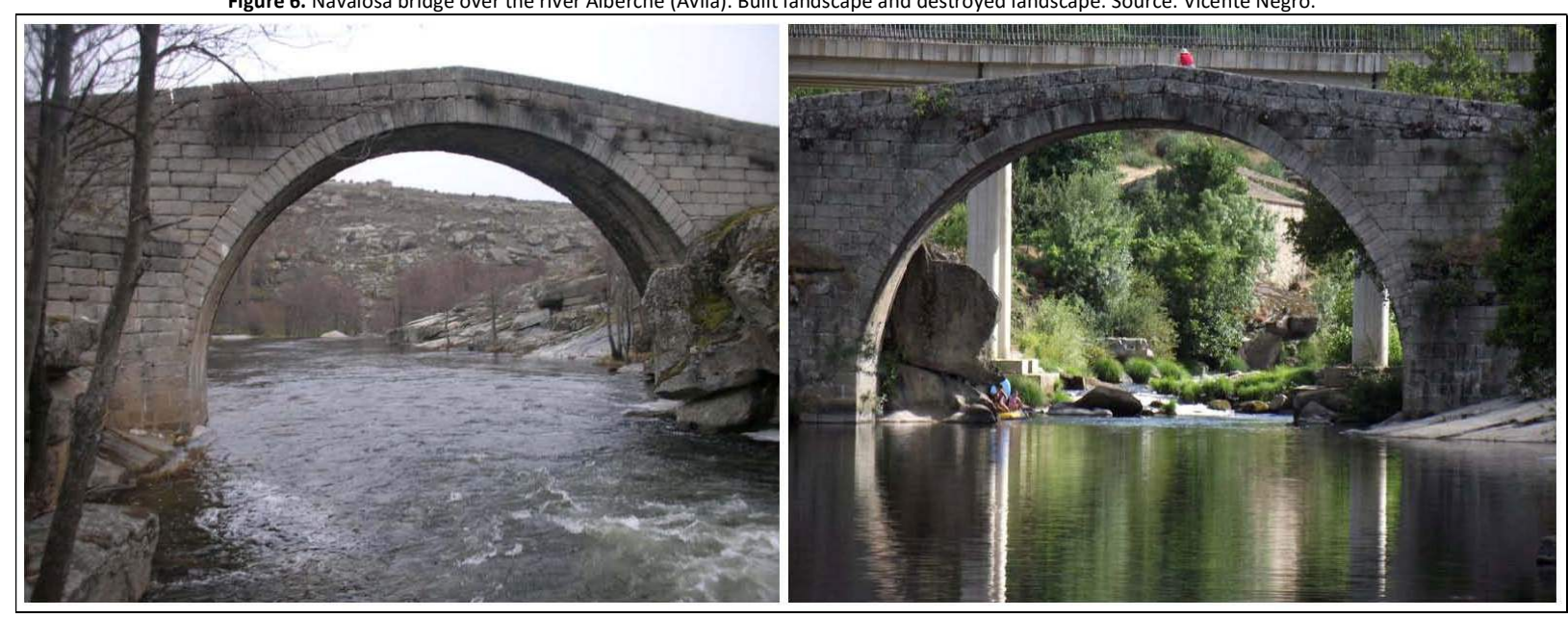

In constructing of roads in mountainous terrain, landscape may be affected to a greater extent than in flat areas. The need for embankments, cuttings, bridges and tunnels, leads to a dispute between two aspects: technical, wanting to be the least expensive; and environmental, seeking to interfere as little as possible with the environment. Road should be in harmony with the surrounding environment and that includes the public on both sides of the road slope and berm as well as the route of the natural landscape in a macroscopic position (Hu et al., 2012).

One of the major aberrations in Spain has occurred in the A-6 road in the ascent to the Piedrafita Pass, producing huge land clearance works that have led to heavy landslides causing the need for protecting it with a cover tunnel (Figure 7). However, in the photo on the left, the integration into the landscape has been achieved in a masterly fashion. The first idea was to build a curved false tunnel, creating a "rhythm" in the perception of the road, making it much more pleasant for drivers and more respectful of the environment. There is not always a perfect solution to the problems of banks; it depends on the characteristics of the landscape (Martín et al., 2012).

Figure 7. False tunnel on the TF-5 road in Garachico (Tenerife) and landslide on the A-6 road in Piedrafita Pass (León). Source: www.ferrovial.com, www.fomento.es 


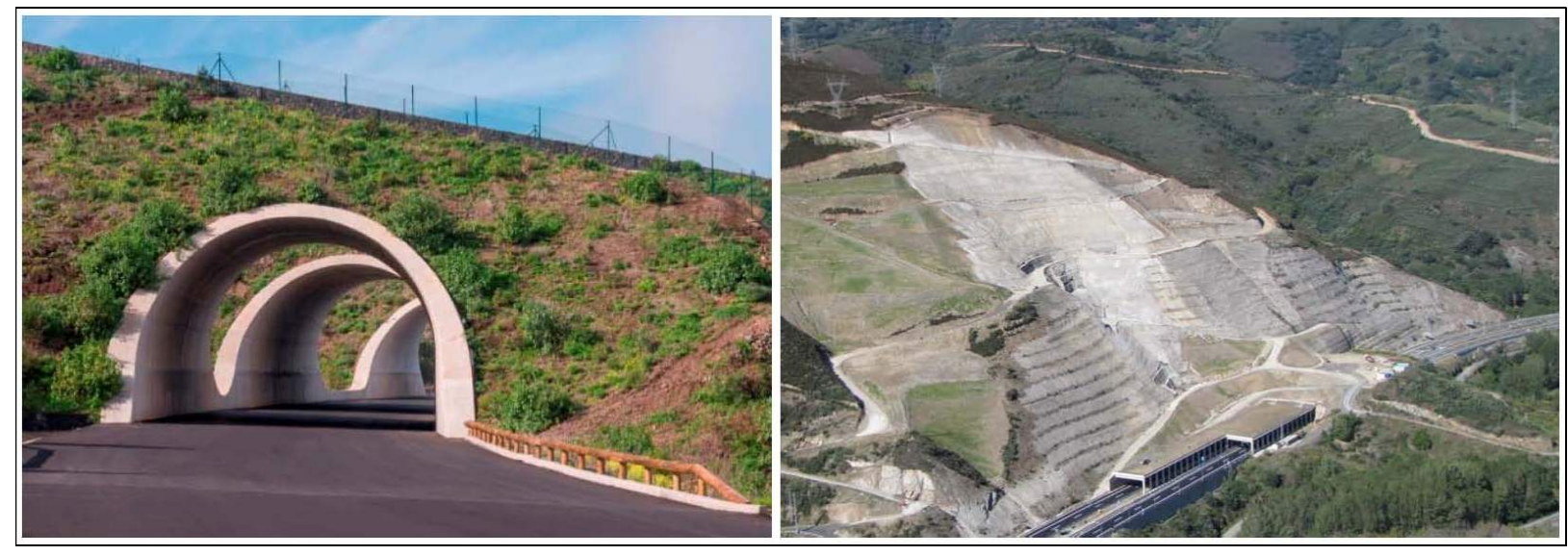

In the field of waterworks, we can also find examples of this difference between built and destroyed landscape. In the case of dams, midstream and downstream landscapes are more affected by construction, becoming more complex and fragmented (Zhao et al., 2012). Alcántara bridge (2nd Century A.D.) is one of the best examples of Roman bridges in the world in terms of conservation, dimensions and importance. For nearly 2000 years this building has survived solitary, and the landscape is not conceived without it. In the late 20th century, with the construction of a dam, everything changed. What was constructed landscape became destroyed, and is also producing further deterioration of the Roman bridge. In some cases, the limit of aesthetic and landscape aspects is exceeded and reaches aspects of heritage conservation. Likewise, the bigger the construction, the heavier and more extended is the impact, as per the example of the Three Gorges Dam on the Yangtze River (China), which is expected to have a major impact not only on ecosystems along the river, but on the Sea as well (Hara et al., 2014).

Figure 8. Almendra dam (Salamanca-Zamora) and Alcántara dam and bridge (Cáceres). Source: www.arribesturismo.es, www.alcantaraenred.es

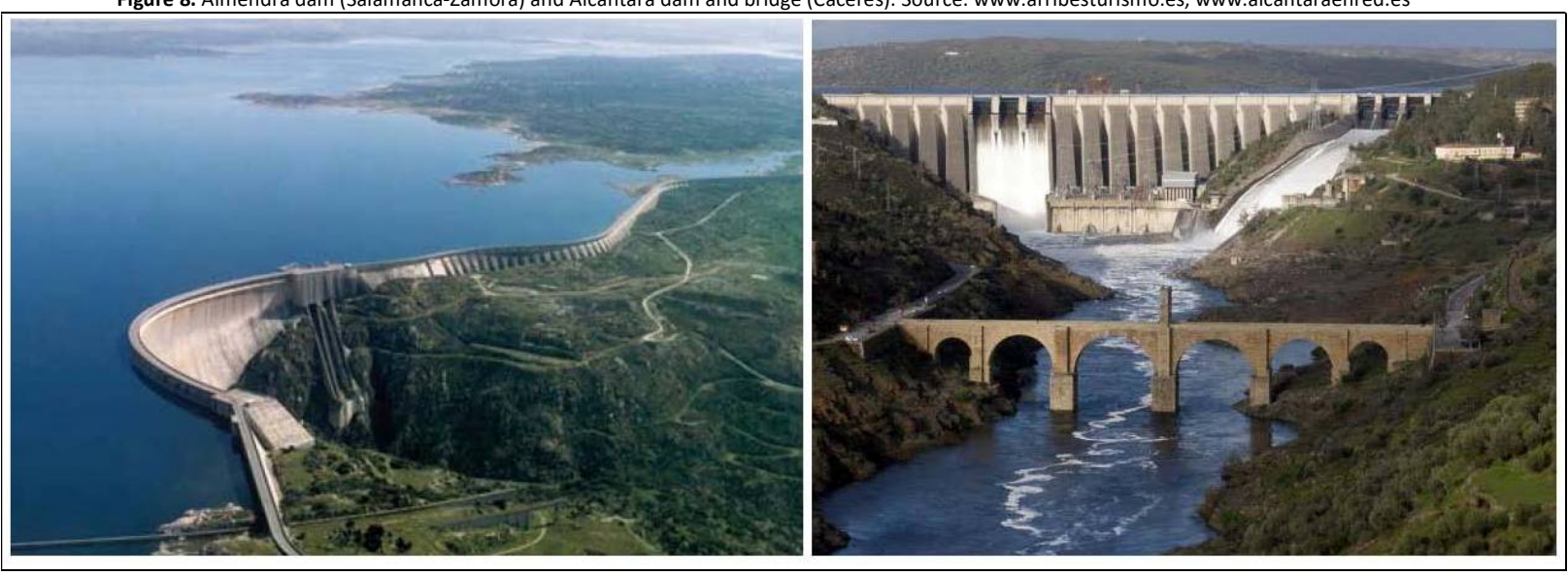

As shown in the first picture (Figure 8), the Almendra dam is much more integrated into the landscape, with its curvilinear forms and the tension occurring when containing reservoir water. Zero impact is impossible since it creates a huge lakeshore, isolating areas previously connected, and transforming the environment into a mosaic of fragmented habitats, but it can sometimes be positive because new surface water produces new wildlife habitats and new uses (Lopes et al., 2014). It is a clear example of how a civil engineering work can improve the landscape in certain aspects and produce a benefit to society, such as electricity production and regulation of river flows. 


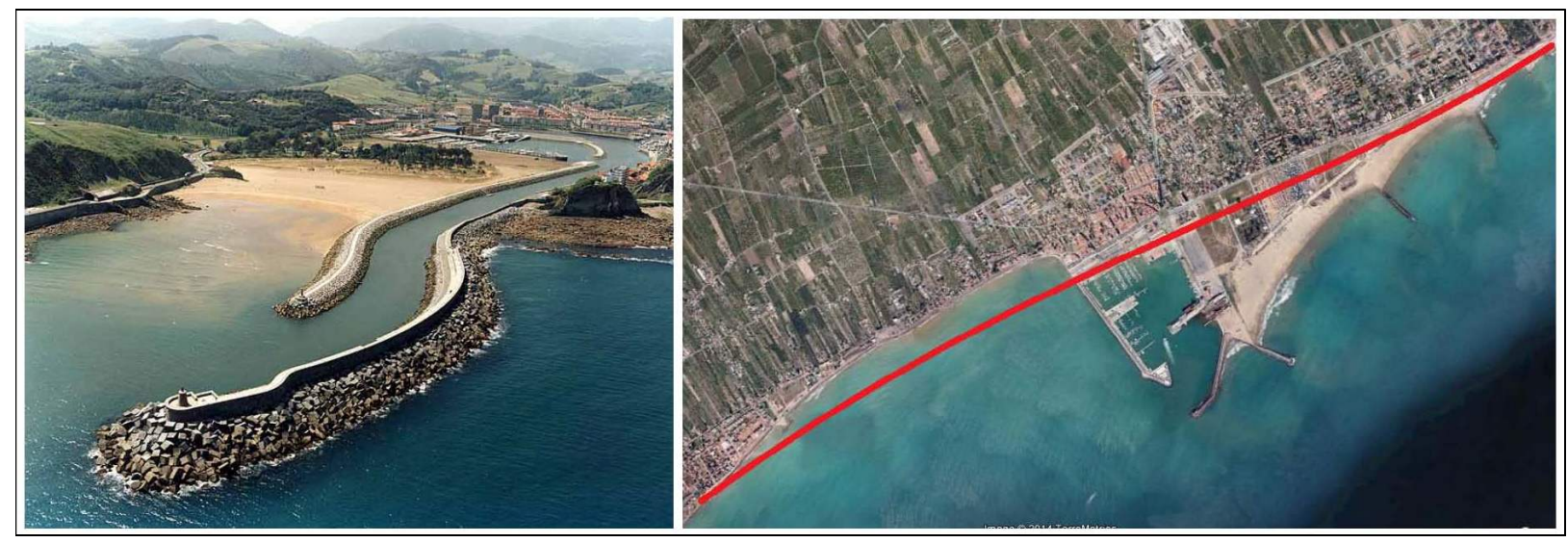

The port is a breach for sailing and led to the birth of the town (Aguiló, 2013). Human activity and contact with the sea combine. The cultural maritime landscape signifies human utilization (economy) of maritime space by boat: settlement, fishing, hunting, shipping and its attendant subcultures, such as pilotage, lighthouse and seamark maintenance (Westerdahl, 1992). However, tourist occupation and change in uses and customs have not made neighborly relations between them good. The town keeps drawing closer to the port and it is now an obstacle, a fence that economic progress and the sun-sand-sea system's value expels (Fusco Girard, 2013). The new system's hierarchy views the constructed landscape as a beach close to the natural one, with a very profound footprint on the weak, fragile and erosive strip that dunes and sand shapes configure. The symbolic frontier which the coast is, the land-sea contact, is taken apart with breakwaters, breaking emotion and creating a deep, rootless regression. The second picture (Figure 9) shows how the Burriana harbour breakwater (Castellón) has become an obstacle to sediment transportation which has led to an increase in the width of beach on the right, and erosion on the left, due to a conservation of mass. On the other hand, with a good study of marine dynamics and sediment transport, and a careful design of shapes, the port can become the seed of new urban planning and the generation of uses in the city that did not exist before, as is the case of Zumaia in Guipúzcoa (Negro, 2008).

The impact on the coast is not only produced by structures at sea, but also by those built on land, many of them more harmful than a breakwater. The coast is a very delicate "living organism", under constant tension and change, so any element that is placed on it will have an effect in some way. The coastline includes an extensive cultural and natural heritage, whether on land or under water, so it has to be examined from a broader point of view in an attempt to cause the least impact possible (Westerdahl, 2006). The problem is that littoral projects are often judged on the basis of a political criteria rather than their functional and formal value for the territory (Aurín \& Muñoz-Pérez, 2002).

Lighthouses are a very particular case. These buildings have been necessary for centuries to guide ships and avoid collisions or grounding near land. Until recently, they played an important role in coastal life. They provided jobs and a home for entire families before technological developments did away with them. Nowadays, many of these buildings are destinations of the "Robinson Tourism", converted into small hotels for single, more educated, well-off and ecologically conscious tourists (Opacic et al., 2010). This tourism can provide benefits and money for the preservation of lighthouses, but the "genius loci" is not the same. 


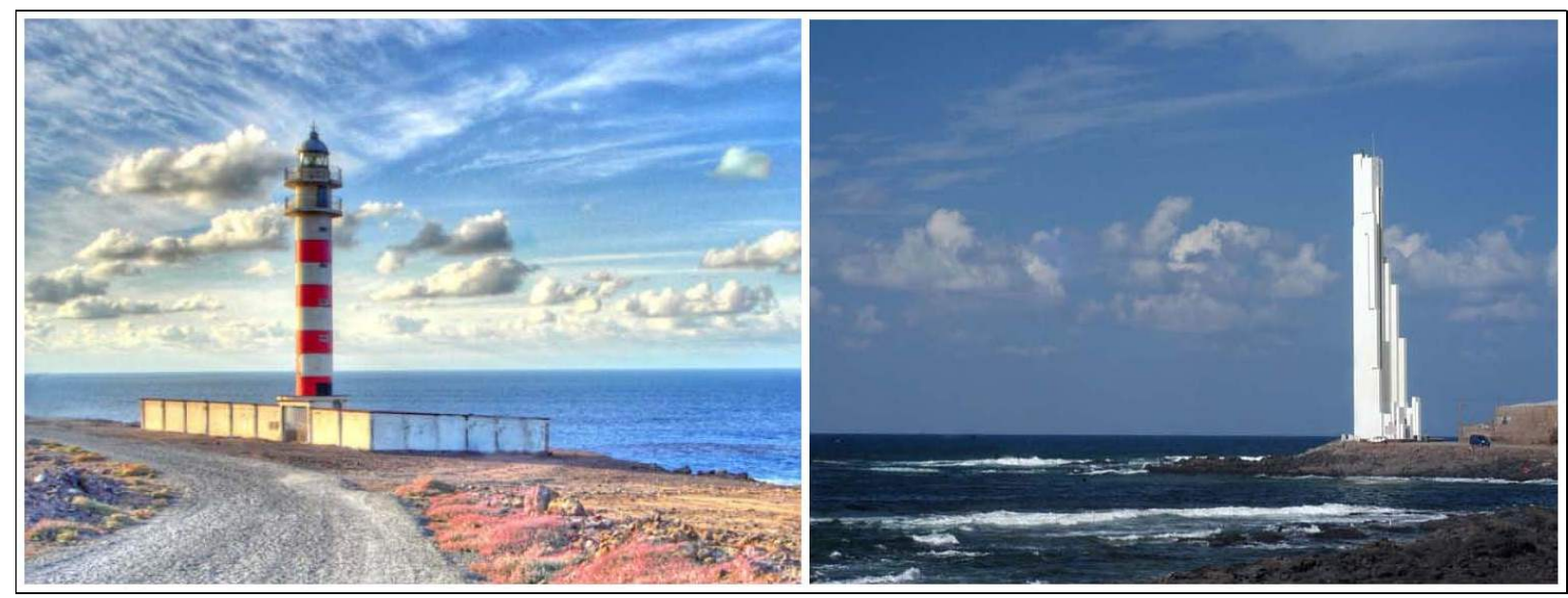

Usually located on high cliffs and natural areas without nearby buildings, lighthouses make of their design a key element when integrated into the landscape. Most lighthouses in the nineteenth century became obsolete and were replaced in the late twentieth century by other automated lighthouses, many of them without much regard in the history and landscape of the place. While in the first picture (Figure 10) the 1980s lighthouse can be seen as keeping the aesthetics of similar, older buildings, the second lighthouse (built in 1992) was intended to alter them by innovating in construction and formal methods and causing a major impact on the fragile coastline, although it fulfils its functions.

Landscapes are combinations of natural and cultural phenomena. We understand that cities are a product of cultural adaptation (Steiner, 2014), but often the natural part is not taken into account in urban development. In coastal areas, especially those of Spain, due to the tourist pressure in recent years, a deeply profound land use mark has occurred, although this phenomenon has been relatively little studied with respect to the actual transformation of the urban landscape and built environment (Hof \& Blázquez-Salom, 2013) and very significantly affects maritime space which is related to both land and sea (Freire, 2013).

The evolution of uses and customs has changed the distribution of water sheltered in harbours. Traditional fishing has given way to boating for sport, providing the town with a "living" for leisure based on the magnificent climate, the many hours of sunlight a year, scarce precipitations and a calm sea suited to recreational boating and for children and grown-ups to be bathed by waves. However, abusive growth, i.e., urban development occupying active beach areas, has created an artificial, harmful, rash landscape in a continuous process of change to artificially restore natural sand areas (Negro, 2014), as can be seen in Santa Pola, Alicante (Figure 11). What has happened to the dune field? What has happened with the east lee shore and the crops? The town's invasion destroys natural landscape with economicist aims, simulated, increasingly larger and less sensitive populations. The town is often not a "place" for coexistence but the clearest example of the insignificant landscape devoid of emotions.

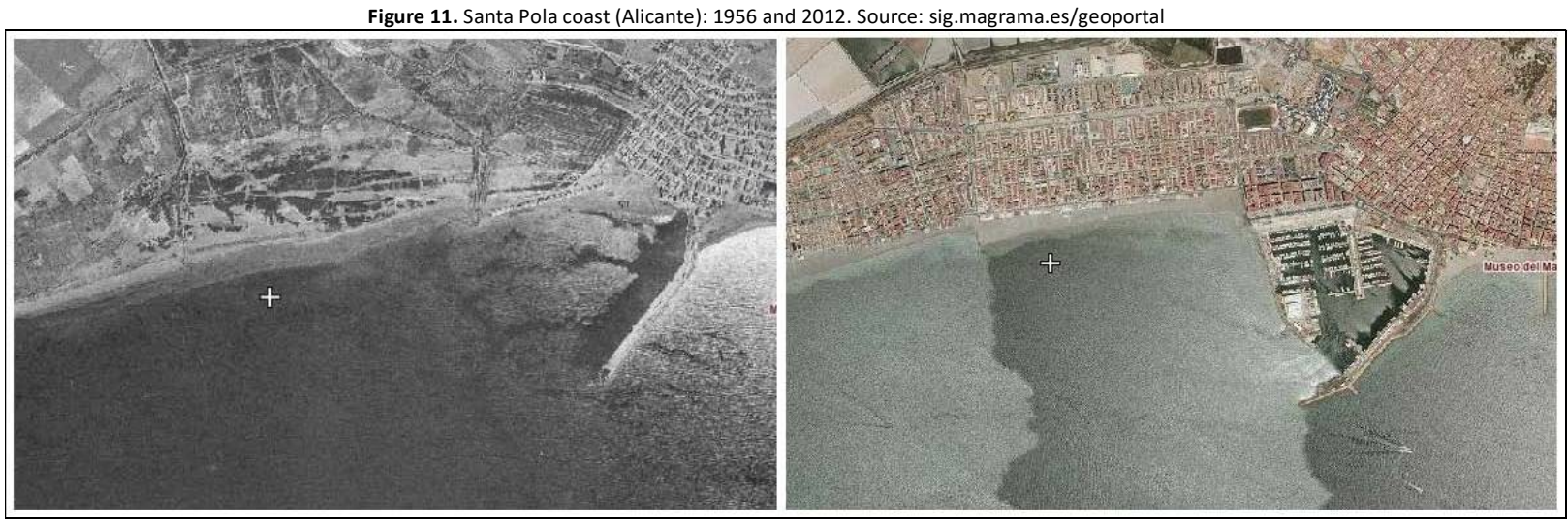


If the coast were a human being, ports would be the arm that shelters, cities, the brains, lighthouses, the eyes and waves, the beating heart that never stops. We must care for all of this to have it living on for many years in the best of health possible.

\section{Conclusion}

This article delves into the relationship of the human being with nature. When the former intends to perpetuate himself in the latter by means of the art of constructing in order to "be in the world" and its constructions, they turn into models of a landscape, a landscape replacing the natural landscape and becoming a constructed one, stamping the concept of "place" on the "site". It endows it with experiences, sensitivity and emotion. It provides it with spirit. How right is the thinking of the philosopher Nietzsche, "If we feel so much at ease in nature, it is because the latter has no opinion of us" (Nietzsche, 1878).

In the same way, engineering as a discipline should seek the "surprise". It should "fit in" rather than "place". It is the localisation of a forgotten location, a lost but found place, an absent but evident element, where the engineer's sensitivity changes what is natural for what is significant and sensitive, providing it with crossing (a bridge), mobility (a road), refuge (a harbour) and experience (a town).

When nature is disorganised, assaulted or attacked, landscape is rash, often destroyed for decades, some in an irreversible manner for the history of time. The natural environment sculptures monuments which the human being should integrate as transcendent rather than crumbling the emotional spirit of the place. A thought of Heidegger sums up this introspection on landscape, on engineering which is not always aesthetic, but that art should be integrated into engineering, "construct into inhabit" and "shape is the guardian of being" (Heidegger, 1947).

Current technology, advances in knowledge of nature's forces and the characteristics of new materials enable us to design real technical marvels, but they should not be at loggerheads with the preservation of the surroundings and conception of "transcendent landscape", even though in most cases, they do not call for the use of such advanced knowledge. Above all, respect as against functionality and economics should prevail.

References

Aguiló, M. (2013). ¿Qué significa construir?: claves conceptuales de la ingeniería civil. Spain: Editorial Adaba. ISBN: 978-8415289760.

Aguiló, M. (1999). El paisaje construido: una aproximación a la idea de lugar. Spain: Colegio de Ingenieros de Caminos, Canales y Puertos. ISBN: 978 8438001523.

Antrop, M. (2005). Why landscapes of the past are important for the future. Landscape and Urban Planning, 70(1-2): 21-34. http://dx.doi.org/10.1016/j.landurbplan.2003.10.002

Du Plessis, C. (2012). Towards a regenerative paradigm for the built environment. Building Research \& Information, 40(1), 7-22 http://dx.doi.org/10.1080/09613218.2012.628548

Freire, J. V. (2013). Maritime Cultural Landscape: A New Approach to the Cascais Coastline. Journal of Maritime Archaeology, 9(1), 143-157. http://dx.doi.org/10.1007/s11457-013-9122-4

Fusco, L. (2013). Toward a Smart Sustainable Development of Port Cities/Areas: The Role of the 'Historic Urban Landscape' Approach. Sustainability, 5(10): 4329-4348. http://dx.doi.org/10.3390/su5104329

González Rodrigo, B., Roig i Olària, S., Fernández-Ordoñez, D. \& Conde-Salazar Gómez, J. M. (2015). Rehabilitation of Historic Masonry Bridges: Lessons Learned from a Medieval Bridge in Northeast Spain. Revista de la construcción, 14(2), 9-13. https://dx.doi.org/10.4067/S0718915X2015000200001

Hara, K., Da, L., Fujihara, M., \& Tomita, M. (2014). Landscape change and sustainable development in the Yangtze River basin, China. Landscape and Ecological Engineering, 10(1), 123-124. http://dx.doi.org/10.1007/s11355-014-0248-9

Heidegger, M. (1947). Platons Lehre von der Wahrheit (Fourth Edition). Vittorio Klostermann.

Hof, A. \& Blázquez-Salom, M. (2013). The Linkages between Real Estate Tourism and Urban Sprawl in Majorca (Balearic Islands, Spain). Land, 2(2) 252-277. http://dx.doi.org/10.3390/land2020252

Hu, S. N., Fan, Q. D., Hu, Z. H., \& Xiao, X. H. (2012). Applications of Visual Characteristics in Highway Alignment Landscape Design. Architecture and Urban Development, 598, 260-263. http://dx.doi.org/10.4028/www.scientific.net/AMR.598.260

Krebs, A. (2014). Why Landscape Beauty Matters. Land, 3(4), 1251-1269. http://dx.doi.org/10.3390/land3041251

Lopes, S. F., Vale, V. S., Prado, J. A., Schiavini, I. \& Oliveira, P. E. (2014). Landscape changes and habitat fragmentation associated with hydroelectric plant reservoirs: insights and perspectives from a central Brazilian case history. Bioscience Journal, 30(4), $1205-1212$. 
Martín, B., Loro, M., Arce, R. M. \& Otero, I. (2012). Different landscaping integration techniques in roads. Analysis of efficacy through public perception. Informes de la Construcción, 64(526), 207-220. http://dx.doi.org/10.3989/ic.11.035

Negro, V. (2008). Las formas en la ingeniería del mar. Revista Ingeniería y Territorio, 84,4-9. ISSN: 1695-9647. 84: 2-12.

Negro, V. (2014). Una aproximación a la percepción de la costa. Revista UPM Universidad Politécnica de Madrid. ISSN: 1699-8162, 27: 10.

Nietzsche, F. (1878). Human, All too Human, a Book for Free Spirits. Ernst Schmeitzner

Norberg-Schulz, C. (1979). Genius Loci: Towards a Phenomenology of Architecture. Rizzoli. ISBN: 0-8478-0287-6

Opacic, V. T., Favro, S., \& Perisic, M. (2010). Tourism valorisation of lighthouses on Croatian islands and along the coast. Island Sustainability, WIT Transactions on Ecology and the Environment, 130, 37-48. http://dx.doi.org/10.2495/ISLANDS100041

Renaud, F., Birkmann, J., Damm, M.; \& Gallopin, G. C. (2010). Understanding multiple thresholds of coupled social-ecological systems exposed to natural hazards as external shocks. Natural Hazards, 55(3), 749-763. http://dx.doi.org/10.1007/s11069-010-9505-x

Sanderson, E. W., Jaiteh, M., Levy, M. A., Redford, K. H., Wannebo, A. V. \& Woolmer, G. (2002). The human footprint and the last of the wild: The human footprint is a global map of human influence on the land surface, which suggests that human beings are stewards of nature, whether we like it or not. BioScience, 52(10): 891-904.

Steiner, F. (2014). Urban Landscape Perspectives. Land, 3(1): 342-350. http://dx.doi.org/10.3390/land3010342

Thompson, C. W. (2002). Urban open space in the 21st century. Landscape and Urban Planning, 60(2): 59-72. http://dx.doi.org/10.1016/S01692046(02)00059-2

Turner, M. G., Gardner, R. H., O’Neill, R. V., \& Pearson, S. M. (1994). Multiscale Organization of Landscape Heterogeneity. In M. E. Jensen \& P. S. Bourgeron Volume II: ecosystem management: principles and applications (73-79). PNW-GTR-318: U.S. Dept. Agric., For. Serv., Pacific North Res. Sta.

Van der Ryn, S., \& Cowan, S. (2007). Ecological Design, 10th Anniversary Edition. Washington, DC., Island Press, Westerdahl, C. (1992). The maritime cultural landscape. International Journal of Nautical Archaeology, 21(1): 5-14. http://dx.doi.org/10.1111/j.1095-9270.1992.tb00336.x

Westerdahl, C. (2006). From river to sea catching the monsoon, concepts of the maritime landscapes. In L. Indo-Portuguese encounters, journeys in science, technology and culture (334-350).

Zhao, Q., Liu, S., Deng, L., Dong, S., Cong, Wang, Yang, Z., \& Yang, J. (2012). Landscape change and hydrologic alteration associated with dam construction. International Journal of Applied Earth Observation and Geoinformation, 16, 17-26. http://dx.doi.org/10.1016/j.jag.2011.11.009 